\title{
Preliminary Assessment of Stock Enhancement in Swimming Crab (Portunus trituberculatus) Based on Molecular Markers
}

\author{
Shanshan Cai ${ }^{1}$, Tianxiang $\mathbf{G a o}^{2}$, Binlun Yan ${ }^{3}$, Aiyi Zhu' ${ }^{1}$ and Xiumei Zhang ${ }^{1,2, *}$ \\ ${ }^{1}$ National Engineering Research Center for Marine Aquaculture, Zhejiang Ocean \\ University, $1^{\text {st }}$ Haidanan Road, Zhoushan, 316022, P.R. China \\ ${ }^{2}$ Key Laboratory of Sustainable Utilization of Technology Research for Fishery \\ Resource of Zhejiang Province, Marine Fisheries Research Institute of Zhejiang, \\ Zhoushan 316021, P.R. China \\ ${ }^{3}$ Jiangsu Key Laboratory of Marine Biotechnology, Huaihai Institute of Technology, \\ $59^{\text {th }}$ Cangwu Road, Lianyungang, 222005, P.R. China
}

\section{A B S T R A C T}

Assessment of the stock enhancement programs is crucial for fishery resources recovery, yet lack of proper methods hinders the precision and accuracy of such assessment. The swimming crab, Portunus trituberculatus is a commercially important species in Chinese fishery industry. However the natural resources of swimming crabs are declining and enhancement programs are being conducted for resources restoration for decades. In this study, 524 female broodstock from 10 hatcheries and 547 recaptured crabs from 6 investigations were used to assess the proportion of released individuals and evaluate the effect of the program in Shandong Province in 2014. Parentage determination between broodstock and recaptured individuals was implemented by using mitochondrial control region fragments and three microsatellite markers. When using mtDNA loci, 242 individuals (44.24\%) were excluded for no shared haplotype with broodstock. Further $81(14.81 \%)$ crabs were identified as hatchery-reared individuals based on microsatellite loci from the remaining 305 crabs. Our results also showed high genetic diversity and a certain degree of heterozygote deficiency of natural swimming crab populations. The advancing technology and its unique advantages will make molecular markers as novel and highly-efficient approaches for assessment of stock enhancement.

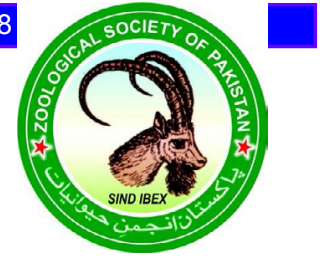

CrossMark

\author{
Article Information \\ Received 01 October 2018 \\ Revised 11 November 2018 \\ Accepted 22 November 2018 \\ Available online 03 October 2019 \\ Authors' Contribution \\ TXG and XMZ designed the research. \\ SSC, BLY and AYZ collected the \\ samples. SSC conducted analysIs and \\ wrote the manuscript. \\ Key words \\ Microsatellite loci, Mitochondrial \\ DNA, Parentage determination, Stock \\ enhancement, Swimming crab.
}

\section{INTRODUCTION}

$\mathrm{T}$ he swimming crab, Portunus trituberculatus is widely distributed in the coastal waters of AsiaPacific countries. As an important crustacean species in commercial fisheries, over 300,000 tons of swimming crabs were caught annually and $98 \%$ were from the coast of China. It is one of the most commercially important species in China and spreads widely throughout the marginal seas of China including the Bohai Sea, the Yellow Sea, the East China Sea and the South China Sea (Dai et al., 1997; Xu et al., 2009). However, natural resources have dramatically declined over the last decades due to the intensive fishing pressure (Zhu et al., 2010). As a result, resources recovery has been taken place across Chinese coastal waters for fishery production and protection of natural resources of swimming crabs.

Stock enhancement programs were implemented in

\footnotetext{
Corresponding author: xiumei1227@163.com 0030-9923/2020/0061-0001 \$ 9.00/0

Copyright 2020 Zoological Society of Pakistan
}

some species, involving hatchery-reared offspring being released into wild environment (Davenport et al., 1999; Sekino et al., 2005; Lorenzen et al., 2010). Releasing is one of the effective methods to improve the resources decline and increase production immediately. The program to recruit the $P$. trituberculatus fishery restoration was taken place in most coastal provinces in China. In Shandong Province for instance, billions of hatcheryraised juvenile crabs (about $10 \mathrm{~mm}$ in body width, J2stages) were released into natural environment from 2005 (Zhang et al., 2009). However the assessment process of the efficiency of enhancement programs was in early stage. Tracking the fates of released individuals in the wild is essential to provide feedback on the adjustment and improvement of various hatchery practices and release strategies (Lorenzen, 2006; Obata et al., 2006). Lack of scientific evaluation system and long-term monitor data impeded assessments of whether there were differences in enhancement effectiveness among various stocking methods, whether there were generally based differences in survival among released species, and whether genetic diversity among hatchery-released individuals differed 
from that among wild ones (Karlsson et al., 2008).

Unmarking technique was used to evaluate the stock enhancement by resources investigation and get a recaptured rate for the program previously (Xie et al., 2014). However unmarking technique is more suitable for rough analysis under the specific situations (Zhang and Ye, 2000). Meanwhile, common tags for marking the juvenile crabs are unsuitable for their exuviate characteristic in the growth period (Okamoto, 1999; Gao et al., 2013). Genetic tag, a novel tag method applied in marine biology studies, may solve these problems. Compared with common tags, the advantage of genetic markers include (i) inner-marker individuals mixed with unmarked released juveniles being survived in the same environment, so the result is closely to actual situation; (ii) depending on broodstock genetic information only instead of complicated work of marking juveniles; (iii) marking without injury; and (vi) monitoring the fluctuation of genetic diversity (Lukacs and Burnham, 2005; Teel et al., 2015). As a popular marking method in stock enhancement, the genetic tag was rarely applied in crustaceans than fish except some typical economic species.

In this study, we chose 10 hatcheries in Shandong
Province to investigate the $P$. trituberculatus stock enhancement program. Two genetic markers, mitochondrial DNA (mtDNA) control region and microsatellite DNA, were sequentially used to distinguish hatchery-reared crabs from landings. Female broodstock and her offspring shared same haplotype for the maternal inheritance of mitochondrial DNA when they possess one same allele in one locus at least for dominant inheritance of microsatellite DNA. The main objectives were to quantify the proportion of hatchery-reared crabs in all recaptured individuals and to evaluate the effectiveness of this program. Another purpose is to provide basic data for possible decline in genetic diversity to ensure a stable and healthy recovery of fishery resources.

\section{MATERIALS AND METHODS}

\section{Ethics statement}

Ethical approval was not required for this study because no endangered animals were involved. All handling of Portunus trituberculatus specimens was conducted in strict accordance with Animal Care Quality Assurance in China.

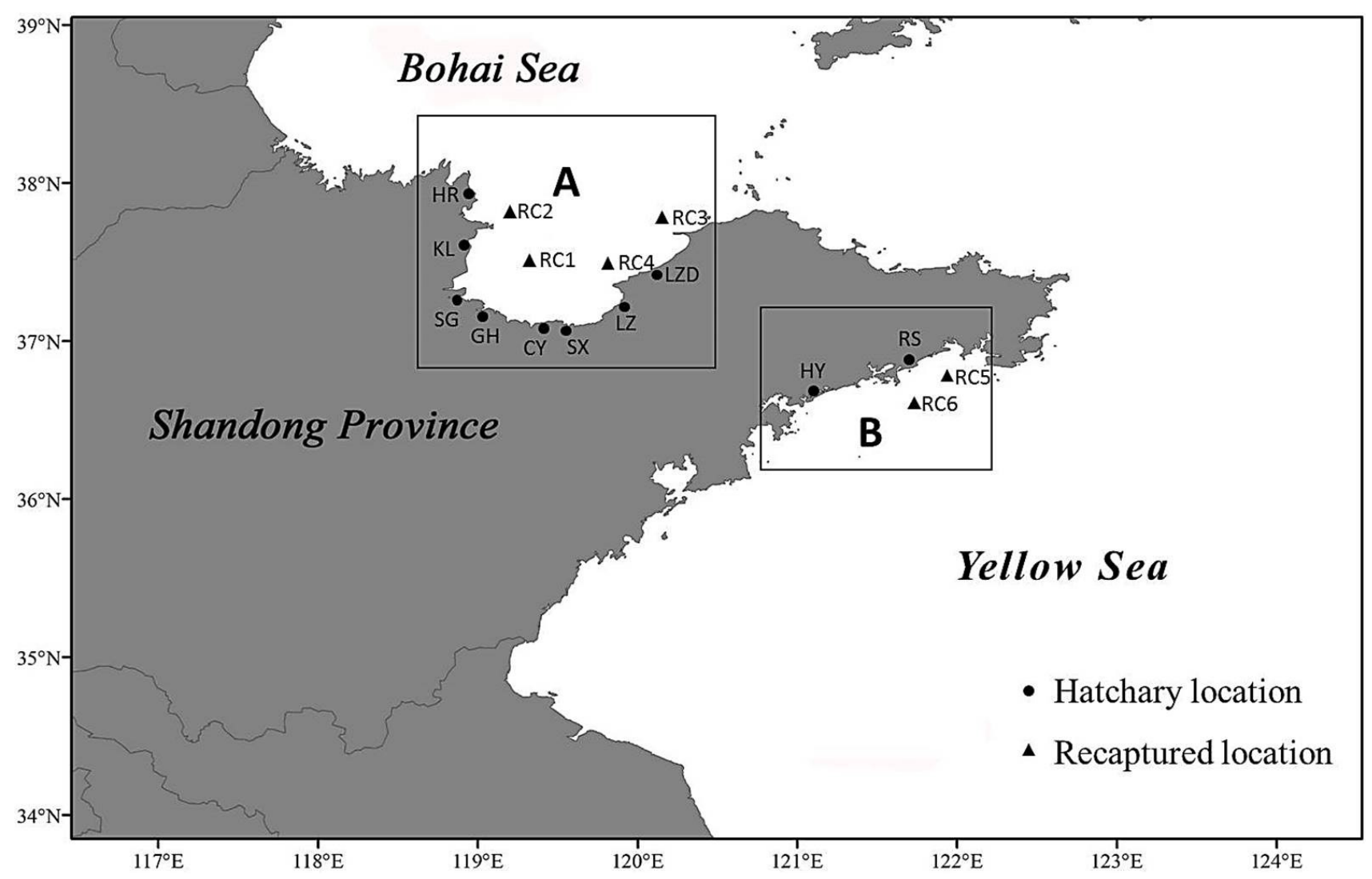

Fig. 1. Samples collected from coastal waters of Shandong Province. A, Nor; B, Est. 


\section{Sample collection}

Spawning and juvenile rearing was carried out by 10 hatcheries in 2014 (Fig. 1; Table I). It is difficult to get the male crab samples due to the mating in autumn however the spawning in spring. Berried female broodstock were collected from coastal waters near each hatchery without male broodstock. A total of 524 berried female broodstock were breed successfully in selected hatcheries and all of they considered broodstock samples. 42.2 million juveniles generated and then temporary reared to J2-stages before releasing. All these offspring were released into bays or estuaries near each hatchery location, lasting from end of May to the early June. In the fall of the same year, six times of recapture surveys were investigated around the coastal waters of Shandong Province and a total of 547 crabs were collected, with width ranged from 7.7$15.9 \mathrm{~cm}$ (Fig. 1; Table II). The swimming crab inhabits in limited regions without rare long migration. As a result, the populations in the north waters of Shandong Province (Laizhou Bay) were supposed to have no communication with the populations in the east. Therefore the samples were divided into Nor and Est parts for further analysis. One pleopod of each broodstock and recaptured crabs were collected and stored in 95\% ethanol for further genome DNA extraction (Gao et al., 2000).

\section{DNA extraction and sequencing}

Genome DNA was extracted using traditional phenol-chloroform protocol method (Sambrook et al., 1989). Mitochondrial control region fragments were amplified by using Primers CR-AR (5'-ACTACACGCAACAACTCTCA-3') and CR-BR (5'-AATCTTTCTGGATTCTCCTA-3'), and the PCR profiles were following Feng's description (Feng et al., 2008). Three pairs of microsatellite primers (pot8, pot 41 , pot62) labeled by fluorescence dye on 5 ' end were selected for microsatellite analysis as described in Han et al. (2012). PCR program was performed in $25 \mu \mathrm{L}$ reactions containing $0.15 \mu \mathrm{L}$ of Taq DNA polymerase, $1 \mu \mathrm{L}$ of template DNA, $1 \mu \mathrm{L}$ of each primer, $1 \mu \mathrm{L}$ of dNTPs, $2.5 \mu \mathrm{L}$ of $10 \times \mathrm{PCR}$ buffer and $18.35 \mu \mathrm{L}$ of ultrapure water. Amplifications were carried out on thermocycler with the following protocol: $5 \mathrm{~min}$ at $94^{\circ} \mathrm{C}, 30$ cycles of $45 \mathrm{~s}$ at $94^{\circ} \mathrm{C}, 45 \mathrm{~s}$ at the annealing temperature and $1 \mathrm{~min}$ at $72^{\circ} \mathrm{C}$, and a final extension at $72^{\circ} \mathrm{C}$ for $10 \mathrm{~min}$. The products were visualized on $1.5 \%$ TAE agarose gels before sent to STR sequencing.

\section{Data analysis}

All mtDNA control region sequences were edited and aligned using DNASTAR software (DNASTAR Inc., Madison, WI, USA). Sequences were aligned using MEGalign software under cluster $\mathrm{W}$ algorithm. The number of genetic haplotype was calculated using DNAsp Software (Librado and Rozas, 2009). STR data were

Table I.- The information of the broodstock and releasing.

\begin{tabular}{lcccc}
\hline Location & $\begin{array}{c}\text { No. of } \\
\text { broodstock }\end{array}$ & $\begin{array}{c}\text { No. of released } \\
\text { juveniles }\left(\times \mathbf{1 0}^{\mathbf{4}}\right)\end{array}$ & $\begin{array}{c}\text { Releasing } \\
\text { time }\end{array}$ & Group \\
\hline CY & 91 & 600 & 2014.06 .07 & Nor \\
GH & 34 & 250 & 2014.06 .10 & Nor \\
HR & 18 & 300 & 2014.06 .13 & Nor \\
KL & 80 & 540 & 2014.06 .08 & Nor \\
LZ & 20 & 400 & 2014.06 .11 & Nor \\
LZD & 26 & 300 & 2014.06 .07 & Nor \\
SG & 81 & 120 & 2014.06 .11 & Nor \\
SX & 61 & 260 & 2014.06 .09 & Nor \\
RS & 56 & 650 & 2014.05 .29 & Est \\
HY & 57 & 800 & 2014.05 .28 & Est \\
Total & 524 & 4220 & - & - \\
\hline
\end{tabular}

Table II.- The information of the recapture surveys.

\begin{tabular}{llcccc}
\hline Location Time & n & $\begin{array}{c}\text { Carapace } \\
\text { width (mm) }\end{array}$ & $\begin{array}{c}\text { Body } \\
\text { weight }(\mathbf{g})\end{array}$ & Group \\
\hline $\mathrm{RC1}$ & $2014.08 .02-08$ & 38 & - & - & Nor \\
$\mathrm{RC} 2$ & 2014.09 .02 & 49 & 136.08 & 125.35 & Nor \\
$\mathrm{RC} 3$ & 2014.09 .05 & 32 & 77.29 & 32.83 & Nor \\
$\mathrm{RC4}$ & 2014.10 .21 & 239 & 159.22 & 241.80 & Nor \\
$\mathrm{RC5}$ & 2014.08 .13 & 108 & 85.31 & 33.69 & Est \\
$\mathrm{RC6}$ & 2014.08 .25 & 81 & 86.25 & 35.01 & Est \\
\hline
\end{tabular}

Table III.- Three characteristics of three microsatellite loci.

\begin{tabular}{lllll}
\hline Locus & Repeat motif & Primer $\left(\mathbf{5}^{\prime}-\mathbf{3}\right.$ ') & Size range (bp) & Tm. $\left({ }^{\circ} \mathbf{C}\right)$ \\
\hline Pot8 & $(\mathrm{GA})_{12}$ & F: FAM-CCACACGAAAAATGCAACTG & $174-239$ & 60 \\
& & R: TCACCGTGCAGAATTGAAAAG & \\
Pot41 & $(\mathrm{GA})_{12}$ & F: HEX-AAAGAACGCGGTCACTGAAT & $154-224$ & 60 \\
& & R: ACACTGAAATTCCGCCAAAG & & 57 \\
Pot62 & $(\mathrm{AC})_{26}$ & F: TAM-CGCTACAGCGACGTAAATA & $143-241$ & \\
& & R: TGCTAGATGAACTGCGACTA & & \\
\hline
\end{tabular}


read by GeneMarker (Holland and Parson, 2011) and recorded in EXCEL format. Gene diversity was calculated using CERVUS (Marshall et al., 1998). Parentage determination and exclusion analyses were estimated using CERVUS between broodstock and recaptured crabs in one haplotype supplemented by artificial correction.

Table IV.- Haplotypes classification of mtDNA control region.

\begin{tabular}{lccc}
\hline Group & $\begin{array}{c}\text { Private } \\
\text { haplotypes of } \\
\text { broodstock }\end{array}$ & $\begin{array}{c}\text { Shared } \\
\text { haplotypes }\end{array}$ & $\begin{array}{c}\text { Private } \\
\text { haplotypes of } \\
\text { recaptured crabs }\end{array}$ \\
\hline Nor & $141(185 b)$ & $53(226 b+245 r)$ & $77(113 r)$ \\
Est & $23(49 b)$ & $16(64 b+60 r)$ & $90(129 r)$ \\
\hline
\end{tabular}

*Specific number of broodstock and recaptured crabs is in brackets. $b$, broodstock; $r$, recaptured crabs.

Table V.- Genetic variation data of three microsatellite loci.

\begin{tabular}{lcccccc}
\hline Loci & $\boldsymbol{K}$ & $\boldsymbol{H}_{\boldsymbol{o}}$ & $\boldsymbol{H}_{\boldsymbol{e}}$ & $\boldsymbol{P I C}$ & $\boldsymbol{P}$ & $\boldsymbol{F}$ (Null) \\
\hline Pot8 & 39 & 0.791 & 0.910 & 0.903 & 0.821 & 0.068 \\
Pot41 & 33 & 0.637 & 0.810 & 0.789 & 0.649 & 0.130 \\
Pot62 & 42 & 0.664 & 0.915 & 0.908 & 0.828 & 0.159 \\
Average & 38 & 0.697 & 0.878 & 0.867 & 0.766 & 0.119 \\
\hline
\end{tabular}

${ }^{*} K$, numbers of alleles; $H_{o}$, observed heterozygosity; $H_{e}$, expected heterozygosity; PIC, polymorphic information content; $P$, probability of exclusion based on the genotype of one parent known by simulation; $F($ Null $)$, Null allele frequency.

\section{RESULTS}

MtDNA control region

A 533-bp segment of control region was sequenced in all individuals. 271 haplotypes were defined among 411 broodstock and 358 recaptured crabs of group Nor. Among them, a total of 218 private haplotypes defined by either broodstock (185 individuals) or recaptured crabs (113 individuals) were eliminated. The remaining 226 broodstock and 245 recaptured crabs defined 53 shared haplotypes. In group Est, 113 broodstock and 189 recaptured individuals defined 129 haplotypes in total. A total of 113 private haplotypes between broodstock and recaptured crabs defined by either 49 broodstock or 129 recaptured individuals were excluded. The rest of 64 broodstock and 60 recaptured crabs defined 16 shared haplotypes (Table IV). In total, $44.24 \%$ recaptured individuals were excluded when investigating mtDNA markers (Table VI). The remaining 290 broodstock and 305 recaptured individuals were retained for further microsatellite analysis.

\section{Microsatellite loci}

The three microsatellite markers used for parentage determination were highly polymorphic in the present study (Table V). Allele numbers for the single locus ranged from 33 (pot41) to 42 (pot62). The high allelic diversity correspondingly manifested into high heterozygosity (Mean $\mathrm{He}=0.878$ ) and high PIC (Mean PIC $=0.867$ ). In case that the genotypes of one parent were known, statistical simulation in CERVUS revealed that the combined probability of exclusion $(P)$ reached $98.92 \%$, indicating a high power for parentage determination.

Based on three microsatellite loci, parentage determination and exclusion were carried out between broodstock and recaptured individuals in the same haplotype. Parent-offspring relationship was determined when identical allele was detected in all three loci. The high percentage of exclusion based on microsatellite loci was $48.04 \%$ and $27.52 \%$ for group Nor and Est respectively (Table VI). The results showed that the rest 81 individuals were hatchery-raised, in which 73 from group Nor and 8 from group Est.

Table VI.- Exclusion of recaptured crabs in $P$. trituberculatus stock enhancement.

\begin{tabular}{lcccc}
\hline Group & $\begin{array}{c}\text { No. of } \\
\text { recaptured } \\
\text { crabs }\end{array}$ & $\begin{array}{c}\text { Exclusion of } \\
\text { mtDNA }\end{array}$ & $\begin{array}{c}\text { Exclusion } \\
\text { of micro- } \\
\text { satellites }\end{array}$ & $\begin{array}{c}\text { Hatchery- } \\
\text { reared }\end{array}$ \\
\hline Nor & 358 & $113(31.56 \%)$ & $172(48.04 \%)$ & $73(20.39 \%)$ \\
Est & 189 & $129(68.25 \%)$ & $52(27.52 \%)$ & $8(4.23 \%)$ \\
Total & 547 & $242(44.24 \%)$ & $224(40.95 \%)$ & $81(14.81 \%)$ \\
\hline
\end{tabular}

\section{DISCUSSION}

While mtDNA control region have an extremely high level of nucleotide variation in genetic analysis (Avise et al., 1987; Sugaya et al., 2008; Guo et al., 2012), it is rarely implemented in parentage assignment of stock enhancement. Only few experiments took it as an assistant tool to get the additional precious conclusion. For instance, in the stock enhancement program of black rockfish (Sebastes inermis), the only four hatcheryreared individuals with ALC were identified exactly from 81 captured fish by mtDNA or one microsatellite locus, respectively (Murakami et al., 2006). For Japanese flounder (Paralichthys olivaceus), the inconsistent result was observed that 41 individuals were distinguished from landings by mtDNA while 35 were identified by four microsatellite loci (Sekino et al., 2005). MtDNA control region fragments have extremely high levels of nucleotide variation, thus outstanding performance can be expected in parentage determination and stock enhancement 
especially in species with high haplotype diversity. In this study, preliminary screening was conducted by mtDNA control region. Approximately half of the recaptured individuals were excluded, which to a large extent reduced the workload for further microsatellite analysis. Given the cost-effectiveness and high-efficiency, mitochondrial control region fragments could be considered as an excellent approach used for the preliminary filtering process in future assessments of enhancement programs.

Microsatellite is one of the most popular markers in genetic research due to its co-dominance, widely distribution and high polymorphism (Estoup et al., 1998; Skaala et al., 2004; Sun et al., 2008). In previous studies, the genetic diversity of crabs involving in stock enhancement was calculated and the results showed a high level in natural waters than in hatchery (Liu et al., 2010). Similarly the results in Liu et al. (2012) also showed $\mathrm{Ho}$ is lower than $\mathrm{He}$ in three loci leading to null allele in the population implied a certain degree of heterozygosity deficiency. It is speculated that the populations offshore influenced by anthropogenic activities greatly and inbreeding frequently within populations to a large extent precipitate the heterozygote deficiency. It is believed that fishery management planners should paid more attention to germplasm resources conservation to avoid risk of declines in genetic diversity.

Parentage determination analyses of stock enhancement have been implemented based on numbers of microsatellite loci for releasing and tracing in some commercial organisms (Norris et al., 2000; Sekino et al., 2003; Jerry et al., 2004; Steele et al., 2013). In this study, three microsatellite markers were used in parentage determination analyses and about half individuals were excluded. Similar to previous experiments in $P$. trituberculatus (Liu et al., 2010, 2016), the combined probability of exclusion $(P)$ reached $98.92 \%$ by using three microsatellite loci in the present study, indicating a huge potential in parentage determination with uniparental information.

Since information such as production of landings were unknown, here the proportion of released individuals in landing crabs was used as the indicator of stock enhancement instead of recapture rates or output-input ratio. Only $14.81 \%$ of recaptured carbs were identified as hatchery-reared, which was much lower than expectation. There are three possible reasons might result in such low proportion: large amount of releasing juveniles or wild individuals diluted our releasing population, high mortality of individuals due to unfitness, environment influence or other reasons and the high intensity of fishing pressure. It is likely that the large numbers of releasing juveniles maybe the main reason for the low proportion of this study.
There is no study published on evaluation of stock enhancement of P. trituberculatus except Xie et al. (2014). They evaluated the effect by using traditional biological investigation and revealed that over $60 \%$ of landing crabs captured in the autumn were hatchery-origin in coast waters of Shandong Peninsula. This method provided a primary data, but the precision and accuracy was limited by environment factors largely. The difference between evaluation approach and hatchery quantity was the inducement of disparity. The chosen of approaches depend on specific situation and each method has their advantages.

Habitat destructions, as well as overfishing made great contribution to the reduction of recruitment of wild $P$. trituberculatus. Resources recovery programs of $P$. trituberculatus such as stock enhancement were carried out in a large scale from 2005 in Shandong Province. It is widely believed that the important economic and fishery resources of the coastal serious decline in Shandong province are clearly complemented by stock enhancement (Zhang et al., 2009). As a result, increasing numbers of hatchery-raised juveniles were released into natural sea unrestrictedly. Actually almost every coastal city in Shandong Province participated in stock enhancement progresses, which is normally viewed as an immediate solution to resources decline, ignoring the substantial ecologic and genetic risk. Further unacclimatization and maladaptation could be revealed gradually when releasing populations were different from wild population in physical or genetic characteristic due to limited broodstock, contribution disequilibrium and hatchery domestication (Dong et al., 2013a, b). Notably, we should largely focus on scientific strategy and environment improvement, rather than the quantities of releasing individuals simply.

It is a complex program of fishery recovery strategy that possess strict procedure from early preparation including parent selection and farming management to later monitor on influence on local species and environment. Recruitments were restricted by several factors: the quality and fitness of releasing individuals (Walters and Juanes, 1993; Caley et al., 1996; Chesson, 1998); the physical and biological constraints (Hughes et al., 1990; Wahle, 2003); and environmental factors imposing controls on population abundances (Kitada et al., 1992; Masuda and Tsukamoto, 1998; Seitz et al., 2008; Affan et al., 2018). As increasing numbers of individuals were released into the natural environment, disadvantages such as inbreeding, competition between releasing and wild population and decline of genetic diversity occurred gradually (Xu et al., 2001; Li et al., 2004; Selly et al., 2014; Grant et al., 2017). Adjustment should be made to ensure the impacts on environment and wild population were within acceptable limits during the program by continual monitoring and 
regular review.

Stock enhancement is an effective and efficient solution to resources recovery for numerous marine species (Grant et al., 2017). However there is no model to follow due to its hugeness and complication. For stock enhancement program, ecological, economic and social benefits are the main objectives and this requires more balance and consideration between releasing and environment. Ideal and successful stock enhancement program requires that such activities should increase the resources and spawning stocks rather than replace the local populations, which is risky for eco-balance and genetic diversity (Secor et al., 2002). The effectiveness of a stock enhancement depends not only on the performance of releasing recruitments but also the fishery management and environmental improvement.

\section{ACKNOWLEDGMENT}

This study was supported by National Program on Key Basic Research Project (973 Program) [2015CB453302], National Natural Science Foundation of China [31472282], Special Scientific Research Funds for Central Non-profit Institutes [2015TS26], International Science and Technology Cooperation Program of China [2015DFR30450] and Public Science and Technology Research Funds Projects of Ocean [201505025].

\section{Statement of conflict of interest}

The authors declare no conflict of interest.

\section{REFERENCES}

Affan, M., Al-Sofyani, A., Turki, A. J. and Hariri, M.S., 2018. Huge Fish killing after rain at Jeddah Coast: The Red Sea, Saudi Arabia. Pakistan J. Zool., 50: 2099-2106. http://dx.doi.org/10.17582/journal. pjz/2018.50.6.2099.2106

Avise, J.C., Arnold, J., Ball, R.M., Bermingham, E., Lamb, T., Neigel, J.E., Reeb, C.A. and Saunders, N.C., 1987. Intraspecific phylogeography: The mitochondrial DNA bridge between population genetics and systematics. Annu. Rev. Ecol. Syst., 18: 489-522. https://doi.org/10.1146/annurev. es. 18.110187 .002421

Caley, M.J., Carr, M.H., Hixon, M.A., Hughes, T.P., Jones, G.P. and Menge, B.A., 1996. Recruitment and the local dynamics of open marine populations. Annu. Rev. Ecol. Syst., 27: 477-500. https://doi. org/10.1146/annurev.ecolsys.27.1.477

Chesson, P., 1998. Recruitment limitation: A theoretical perspective. Austral. Ecol., 23: 234-240. https:// doi.org/10.1111/j.1442-9993.1998.tb00725.x

Dai, A.Y., Feng, Z.Q., Song, Y.Z., Huang, Z.X. and Wu, H.C., 1997. Trituberculatus fishery resources in the preliminary investigation. J. Zool., 2: 30-33.

Davenport, J., Suk, E., Walgama, S.A., Lee, D. and Hills, J.M., 1999. Successful stock enhancement of a lagoon prawn fishery at Rekawa, Sri Lanka using cultured post-larvae of penaeid shrimp. Aquaculture, 180: 65-78. https://doi.org/10.1016/ S0044-8486(99)00141-6

Dong, Z.G., Li, X.Y., Wang, P.L., Wang, W.J., Zhang, Q.Q., Yan, B.L. and Sun, X.W., 2013 a. Genetic diversity and genetic differentiation of swimming crab (Portunus trituberculatus) from six geographical populations of China Sea based on mitochondrial D-loop gene. J. Fish. China, 37: 1304-1312. https://doi.org/10.3724/ SP.J.1231.2013.38630

Dong, Z.G., Li, X.Y., Zhang, Q.Q., Yan, B.L. and Sun, X.W., 2013b. Genetic impact of swimming crab Portunus trituberculatus farming on wild genetic resources in Haizhou Bay. Acta Ecol. Sin., 33: 73327339. https://doi.org/10.5846/stxb201208191164

Estoup, A., Gharbi, K., Sancristobal, M., Chevalet, C., Haffray, P. and Guyomard, R., 1998. Parentage assignment using microsatellites in turbot (Scophthalmus maximus) and rainbow trout (Oncorhynchus mykiss) hatchery populations. Can. J. Fish. aquat. Sci., 55: 715-723. https://doi. org/10.1139/f97-268

Feng, B.B., Li, J.L., Niu, D.H., Chen, L., Zhou, Z.Q., Zheng, Y.F. and Zheng, K.H., 2008. Sequence analysis of mitochondrial putative control region gene fragments of wild Portunus trituberculatus in four sea regions in China. J. Shanghai Fish. Univ., 17: 134-139.

Gao, B.Q., Liu, P., Li, J. and Wang, Q.Y., 2013. Two types of tagging techniques for Portunus trituberculatus. Progr. Fish. Sci., 34: 87-93.

Gao, T.X., Zhang, X.M., Zeng, X.Q. and Watanabe, S., 2000. DNA extraction and PCR amplification from preserved samples. J. Ocean Univ. Qingdao, 30: 244-248.

Grant, W.S., Jasper, J., Bekkevold, D. and Adkison, M., 2017. Responsible genetic approach to stock restoration, sea ranching and stock enhancement of marine fishes and invertebrates. Rev. Fish. Biol. Fisher., 27: 615-649. https://doi.org/10.1007/ s11160-017-9489-7

Guo, E.M., Liu, Y., Cui, Z.X., Li, X., Cheng, Y. and Wu, X., 2012. Genetic variation and population structure of swimming crab (Portunus trituberculatus) 
inferred from mitochondrial control region. Mol. Biol. Rep., 39: 1453-1463. https://doi.org/10.1007/ s11033-011-0882-3

Han, Z.K., Liu, P., Li, J., Gao, B.Q. and Chen, P., 2012. Screening and evaluation of Portunus trituberculatus polymorphic microsatellite DNA markers. Progr. Fish. Sci., 33: 72-78.

Holland, M.M. and Parson, W., 2011. GeneMarker ${ }^{\circledR}$ HID: A reliable software tool for the analysis of forensic STR data. J. Foren. Sci., 56: 29-35. https:// doi.org/10.1111/j.1556-4029.2010.01565.x

Hughes, T.P., Baird, R.A.H., Dinsdale, E.A., Moltschaniwskyj, N.A., Pratchett, M.S., Tanner, J.E. and Willis, B.L., 1990. Recruitment limitation, mortality, and population regulation in open systems: A case study. Ecology, 71: 12-20. https:// doi.org/10.2307/1940242

Jerry, D.R., Preston, N.P., Crocos, P.J., Keys, S., Meadows, J.R.S. and Li, Y., 2004. Parentage determination of Kuruma shrimp Penaeus (Marsupenaeus) japonicus using microsatellite markers (Bate). Aquaculture, 235: 237-247. https:// doi.org/10.1016/j.aquaculture.2004.01.019

Karlsson, S., Saillant, E., Bumguardner, B.W., Vega, R.R. and Gold, G.R., 2008. Genetic identification of hatchery-released red drum in Texas bays and estuaries. N. Am. J. Fish. Manage., 28: 1294-1304. https://doi.org/10.1577/M07-181.1

Kitada, S., Taga, Y. and Kishino, H., 1992. Effectiveness of a stock enhancement program evaluated by a two-stage sampling survey of commercial landings.. Can. J. Fish. aquat. Sci., 49: 1573-1582. https://doi.org/10.1139/f92-175

Li, Q., Park, C., Endo, T. and Kijima, A., 2004. Loss of genetic variation at microsatellite loci in hatchery strains of the Pacific abalone (Haliotis discus hannai). Aquaculture, 235: 207-222. https://doi. org/10.1016/j.aquaculture.2003.12.018

Librado, P. and Rozas, J., 2009. DnaSP v5: A software for comprehensive analysis of DNA polymorphism data. Bioinformatics, 25: 1451-1452. https://doi. org/10.1093/bioinformatics/btp187

Liu, H.Y., Lv, H.B., Cui, F., Xie, W.Y., Li, B.B., Wang, L.S., Liu, Q., Chen, L., Xing, K., Wang, X.H., Shi, H. and Song, B., 2016. Parental contribution and genetic diversity between broodstock and offsprings in swimming crab (Portunus trituberculatus) releasing into natural waters. Fish. Sci., 35: 613619.

Liu, L., Li, J., Liu, P., Gao, B.Q., Chen, P., Dai, Y.F. and Wang, X.Z., 2010. Application of microsatellite DNA markers in parentage determination of
Portunus trituberculatus. Progr. Fish. Sci., 31: 7682.

Liu, Y.G., Guo, Y.H., Hao, J. and Liu, L.X., 2012. Genetic diversity of swimming crab (Portunus trituberculatus) populations from Shandong Peninsula as assessed by microsatellite markers. Biochem. Syst. Ecol., 41: 91-97. https://doi. org/10.1016/j.bse.2011.12.024

Lorenzen, K., 2006. Population management in fisheries enhancement: Gaining key information from release experiments through use of a sizedependent mortality model. Fish. Res., 80: 19-27. https://doi.org/10.1016/j.fishres.2006.03.010

Lorenzen, K., Leber, K.M. and Blankenship, H.L., 2010. Responsible approach to marine stock enhancement: An update. Rev. Fish. Sci., 18: 189210. https://doi.org/10.1080/10641262.2010.49156 4

Lukacs, P.M. and Burnham, K.P., 2005. Review of capture-recapture methods applicable to noninvasive genetic sampling. Mol. Ecol., 14: 3909-3019. https://doi.org/10.1111/j.1365294X.2005.02717.x

Marshall, T.C., Slate, J., Kruuk, L.E.B. and Pemberton, J.M., 1998. Statistical confidence for likelihoodbased paternity inference in natural populations. Mol. Ecol., 7: 639-655. http://dx.doi.org/10.1046/ j.1365-294x.1998.00374.x

Masuda, R. and Tsukamoto, K., 1998. Stock enhancement in Japan: Review and perspective. $B$. Mar. Sci., 62: 337-358.

Murakami, T., Aida, S., Yoshioka, K., Yoshida, H., Blanco, G.E., Nishibori, M. and Tomoya, M., 2006. Mitochondrial DNA and microsatellite DNA as genetic tags for stocked population of black rockfish Sebastes inermis of hatchery origin. Nippon Suisan Gakk., 72: 710-716. https://doi. org/10.2331/suisan.72.710

Norris, A.T., Bradley, D.G. and Cunningham, E.P., 2000. Parentage and relatedness determination in farmed Atlantic salmon (Salmo salar) using microsatellite markers. Aquaculture, 182: 73-83. https://doi.org/10.1016/S0044-8486(99)00247-1

Obata, Y., Imai, H., Kitakado, T., Hamasaki, K. and Kitada, S., 2006. The contribution of stocked mud crabs Scylla paramamosain to commercial catches in Japan, estimated using a genetic stock identification technique. Fish. Res., 80: 113-121. https://doi.org/10.1016/j.fishres.2006.03.016

Okamoto, K., 1999. Tag retention, growth, and survival of the swimming crab, Portunus trituberculatus marked with coded wire tags. B. Japanese Soc. 
Sci. Fish., 65: 703-708. https://doi.org/10.2331/ suisan.65.703

Sambrook, J., Fritsch, E.F. and Maniatis, T., 1989. Molecular cloning: A laboratory manual, $2^{\text {nd }}$ ed. Cold Spring Harbor Laboratory Press, New York.

Secor, D.H., Hines, A.H. and Place, A.R., 2002. Japanese hatchery-based stock enhancement: Lessons for the Chesapeake Bay blue crab. Maryland Sea Grant, Maryland.

Seitz, R.D., Lipcius, R.N., Knick, K.E., Seebo, M.S., Long, W.C., Brylawski, B.J. and Smith, A., 2008. Stock enhancement and carrying capacity of blue crab nursery habitats in Chesapeake Bay. Rev. Fish. Sci., 16: 329-337. https://doi. org/10.1080/10641260701696985

Sekino, M., Saitoh, K., Yamada, T., Hara, M. and Yamashita, Y., 2005. Genetic tagging of released Japanese flounder (Paralichthys olivaceus) based on polymorphic DNA markers. Aquaculture, 244: 49-61. https://doi.org/10.1016/j. aquaculture.2004.11.006

Sekino, M., Saitoh, K., Yamada, T., Kumagai, A., Hara, M. and Yamashita, Y., 2003. Microsatellite-based pedigree tracing in a Japanese flounder Paralichthys olivaceus hatchery strain: Implications for hatchery management related to stock enhancement program. Aquaculture, 221: 255-263. https://doi. org/10.1016/S0044-8486(02)00667-1

Selly, S.C., Hickey, J. and Stevens, J.R., 2014. A tale of two hatcheries: Assessing bias in the hatchery process for Atlantic salmon (Salmo salar L.). Aquaculture, 434: 254-263. https://doi. org/10.1016/j.aquaculture.2014.07.031

Skaala, O., Hoyheim, B., Glover, K. and Dahle, G., 2004. Microsatellite analysis in domesticated and wild Atlantic salmon (Salmo salar L.): Allelic diversity and identification of individuals. Aquaculture, 240: 131-143. https://doi.org/10.1016/j. aquaculture.2004.07.009

Steele, C.A., Anderson, E.C., Ackerman, M.W., Hess, M.A., Campbell, N.R., Narum, S.R. and Campbell, M.R., 2013. A validation of parentage-based tagging using hatchery steelhead in the Snake River basin. Can. J. Fish. aquat. Sci., 70: 1046-1054. https://doi.org/10.1139/cjfas-2012-0451

Sugaya, T., Sato, M., Yokoyama, E., Nemoto, Y., Fujita, T., Okouchi, H., Hamasaki, K. and Kitada, S., 2008. Population genetic structure and variability of Pacific herring Clupea pallasii in the stocking area along the Pacific coast of northern Japan. Fish. Sci., 74: 579-588. https://doi.org/10.1111/j.14442906.2008.01561.x
Sun, X.W., Zhang, X.F., Zhao, Y.Y., Zhang, Y., Jia, Z.Y., Chang, Y.M., Lu, C.Y. and Liang, L.Q., 2008. Development and application of microsatellite markers in aquatic species. J. Fish. Sci. China, 15: 689-703.

Teel, D.J., Burke, B.J., Kuligowski, D.R., Morgan, C.A. and Doornik, D.M.V., 2015. Genetic identification of chinook salmon: Stock-specific distributions of juveniles along the Washington and Oregon coasts. Mar. Coast. Fish., 7: 274-300. https://doi.org/10.10 80/19425120.2015.1045961

Wahle, A.R., 2003. Revealing stock-recruitment relationships in lobsters and crabs: is experimental ecology the key? Fish. Res., 65: 3-32. https://doi. org/10.1016/j.fishres.2003.09.004

Walters, J.C. and Juanes, F., 1993. Recruitment limitation as a consequence of natural selection for use of restricted feeding habitats and predation risk taking by juvenile fishes. Can. J. Fish. aquat. Sci., 50: 2058-2070. https://doi.org/10.1139/f93-229

Xie, Z.Q., Qiu, S.Y., Hou, C.W. and Jin, X.S., 2014. Recapture rates of swimming crab (Portunus trituberculatus) released in the water off southern Shandong Peninsula. J. Fish. Sci. China, 21: 10001009.

Xu, Q.H., Liu, R.L. and Liu, Y., 2009. Genetic population structure of the swimming crab, Portunus trituberculatus in the East China Sea based on mtDNA 16S rRNA sequences. J. exp. Mar. Biol. Ecol., 371: 121-129. https://doi.org/10.1016/j. jembe.2009.01.014

Xu, Z.K., Primavera, J.H., Pena, L.D., Pettit, P., Belak, J. and Warren, A.A., 2001. Genetic diversity of wild and cultured Black Tiger shrimp (Penaeus monodon) in the Philippines using microsatellites. Aquaculture, 199: 13-40. https://doi.org/10.1016/ S0044-8486(00)00535-4

Zhang, C.M. and Ye, Q.T., 2000. The releasing technique and the enhancement effect on the small post larvae of Penaeus orientalis in Dongwuyang Bay. J. Fish. China, 24: 134-139.

Zhang, X.M., Wang, X.J., Tu, Z., Zhang, P.D., Wang, Y.Z., Gao, T.X. and Wang, S.J., 2009. Current status and prospect of fisheries resource enhancement in Shandong Province. Chinese Fish. Econ., 27: 5158.

Zhu, C.K., Wang, W.M., Yan, B.L., Gul, Y. and Wang, H.L., 2010. Development of polymorphic microsatellite markers for the swimming crab, Portunus trituberculatus (Miers, 1876). Conserv. Genet. Resour., 2: 117-119. https://doi.org/10.1007/ s12686-010-9227-0 